\title{
THE LOCALIZATION OF ECERIFERUM LOCI IN BARLEY V. THREE POINT TESTS OF GENES ON CHROMOSOME 1 AND 3 IN BARLEY
}

\author{
by \\ BODIL SØGAARD \\ Agricultural Research Department-Research Establishment Ris $\emptyset$, \\ DK-4000 Roskilde \\ and \\ Department of Physiology, Carlsberg Laboratory \\ Gamle Carlsbergvej 10 - DK-2500 Copenhagen, Valby
}

\begin{abstract}
Key words: Hordeum vulgare, erectoides, albina, bracteatum, chlorina, virescent, semibracteatum, linkage maps
\end{abstract}

Five three point tests are reported for chromosome 1 and four three point tests for chromosome 3 . The tests were analysed in the $F_{1}$ generation.

Maps for two regions on chromosome 1 comprising five and four genes respectively, can be constructed from the data obtained. The map spanning the distance cer-f to ert- $m$ confirms previous results for this interval. As observed earlier, coefficients of coincidence larger than 1 corresponding to negative interference are found in this region of chromosome 1. It is suggested that the consistent occurrence of negative interference in this interval is due to its location close to the centromere. In the other region studied on chromosome 1 normal positive interference is observed.

On chromosome 3 a linkage map of the four markers analysed is presented. Positive interference is found in the three point tests of this region.

\section{INTRODUCTION}

In a previous paper (24) a linkage map comprising five barley genes on chromosome 1 , namely eceriferum cer-f, albina $a c_{2}$, erectoides $e r t-d$, ert- $a$ and ert- $m$ has been presented. In all three point tests involving these genes more double crossovers were observed than expected from the frequencies of crossover in each of the two intervals covered by the three markers. This result was surprising and I have therefore repeated these three tests and can confirm the occurrence of negative interference in this region of chromosome 1 .
In order to investigate whether negative interference is a common characteristic for chromosome 1 markers in barley a different region on chromosome 1 has been studied by three point tests. The region contains the four genes virescent $y c$, chlorina $f c$, ecriferum cer-a and brachytic $b r$. Normal positive interference was obtained in two three point tests involving these markers.

One region on chromosome 3 has been mapped with four three point tests involving 


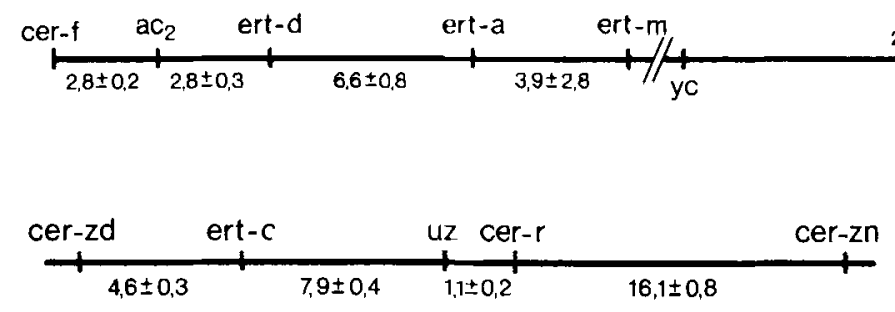

$1,8 \pm 1,5$

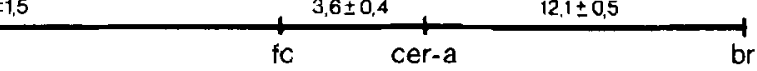

Figure 1. Sequence, distances and standard deviations based on the maximum likelihood method of calculation for the nine genes on chromosome 1.

Figure 2. Sequence, distances and standard deviations based on the maximum likelihood methods of calculation for the five genes on chromosome 3 .

five genes: eceriferum cer-zd, cer-r and cer-zn, erectoides ert-c and semibrachytic $u z$. Normal positive interference is found in this region. The maps derived are given in Figures 1 and 2.

\section{MATERIALS AND METHODS}

The mutants used as markers have been either indueed in the cultivar Svalof's Bonus or have been transferred by repeated back crossing into Bonus background by PERson \& Hagberg (17). The following mutants have been employed:

albina
erectoides
erectoides
erectoides
eceriferum
eceriferum
brachytic
chlorina
virescent
semibrachytic
erectoides
eceriferum
eceriferum
eceriferum

phytotron (3) and analyses were carried out as described in the previous paper of this series (25).

Plants homozygous for the chlorina marker $f c$ are of poor viability in mixed stands with phenotypically normal plants. Many chlorina plants die before heading and they were therefore in the $F_{2}$ rows tagged and counted at the three leaf stage as well as at harvest time. The surviving chlorina plants were sown
Form crosses involving these mutants $(21,22,23)$ the following double mutant lines have been isolated: ert- $a^{23}$ cer-f $f^{9}$, ert- $d^{33}$ cer- $f^{9}$, ert- $m^{40}$ cer-f", br cer- $a^{1}, u z$ cer-r ${ }^{19}$, ert-c $c^{39}$ cer-z $z n^{244}, u z$ cer-z $n^{244}$, ert-c ${ }^{39} c e r-r^{19}$. Each of these double mutant lines was crossed with one or more markers. The combinations in the nine three point tests are given in Table I, where the linked markers in coupling phase from the double mutant lines are designated as $m$ and $c$. The marker of the other parent which then is present in the $F_{1}$ in repulsion phase is designated as $r$. Crosses, growth of the material in the field or the

$\begin{array}{ll}a c_{2} & (19) \\ e r t-a^{23} & (16,8,22) \\ e r t-d^{33} & (16) \\ e r t-m^{40} & (16) \\ c e r-f^{\rho} & (11,21) \\ c e r-a^{1} & (11,8) \\ b r & (18) \\ f c & (19) \\ y c & (19) \\ u z & (26) \\ e r t-c^{39} & (16) \\ c e r-r^{19} & (11,22) \\ c e r-z d^{67} & (11,8) \\ c e r-z n^{244} & (12,21,22)\end{array}$

separately in the $F_{3}$ generation to avoid competition with normal plants.

\section{RESULTS AND DISCUSSION}

3.1. Chromosome 1

The observed number of plants in the 18 viable genotype classes of the three point tests number 1 to 4 and in the 27 viable genotype classes in test number 5 are listed in Table II. In the latter 
Table I

The gene combinations analysed in nine three point tests. The letters $m$ and $c$ designate the markers which are in coupling; and $r$ designates the marker which is in repulsion with respect to $\mathrm{m}$ and $\mathrm{c}$.

\begin{tabular}{c|c|l|l|l}
\hline Chromosome & Test number & $\mathrm{m}$ & $\mathrm{c}$ & $\mathrm{r}$ \\
\hline 1 & 1 & $e r t-d^{33}$ & $c e r-f^{9}$ & $a c_{2}$ \\
1 & 2 & $e r t-m^{40}$ & $c e r-f^{9}$ & $a c_{2}$ \\
1 & 3 & $e r t-a^{23}$ & $c e r-f^{9}$ & $a c_{2}$ \\
1 & 4 & $b r$ & $c e r-a^{1}$ & $y c$ \\
1 & 5 & $b r$ & $c e r-a^{1}$ & $f c$ \\
3 & 6 & $u z$ & $c e r-r^{19}$ & $c e r-z d^{67}$ \\
3 & 7 & $c e r-z n^{244}$ & $e r t-c^{39}$ & $c e r-z d^{67}$ \\
3 & 8 & $u z$ & $c e r-z n^{244}$ & $c e r-z d^{67}$ \\
3 & 9 & $c e r-r^{19}$ & $e r t-c^{39}$ & $c e r-z d^{67}$ \\
\hline
\end{tabular}

Table II

Observed number of $F_{2}$ plants in the 27 genotype classes from nine three point tests.

$M=$ wildtype allele; $m=$ the mutant allele which is in coupling with $c$

$\mathrm{C}=$ wildtype allele; $\mathrm{c}=$ the mutant allele which is in coupling with $\mathrm{m}$

$R=$ wildtype allele; $r=$ the mutant allele in repulsion to $c$ and $m$

Figures in parenthesis under test 5 refer to the number of plants after correction for sublethality of the genotype fcfc.

\begin{tabular}{|c|c|c|c|c|c|c|c|c|c|}
\hline \multirow[b]{2}{*}{ Genotype } & \multicolumn{2}{|c|}{ Test number } & \multirow[b]{2}{*}{3} & \multirow[b]{2}{*}{4} & \multirow[b]{2}{*}{5} & \multirow[b]{2}{*}{6} & \multirow[b]{2}{*}{7} & \multirow[b]{2}{*}{8} & \multirow[b]{2}{*}{9} \\
\hline & 1 & 2 & & & & & & & \\
\hline $1 \mathrm{MmCcRr}$ & 824 & 547 & 504 & 309 & 415 & 620 & 279 & 399 & 447 \\
\hline $2 \mathrm{mmccRR}$ & 409 & 270 & 248 & 127 & 197 & 297 & 118 & 189 & 217 \\
\hline $3 \mathrm{MMCCrr}$ & - & - & - & - & $153(205)$ & 300 & 125 & 185 & 222 \\
\hline $4 \mathrm{MmCCrr}$ & - & - & - & - & $34(52)$ & 0 & 85 & 3 & 48 \\
\hline $5 \mathrm{MmccRR}$ & 17 & 83 & 48 & 45 & 58 & 0 & 81 & 1 & 44 \\
\hline $6 \mathrm{MMCcRr}$ & 18 & 83 & 46 & 48 & 59 & 2 & 86 & 7 & 46 \\
\hline $7 \mathrm{mmCcRr}$ & 23 & 81 & 48 & 40 & 56 & 3 & 88 & 6 & 43 \\
\hline $8 \mathrm{mmccRr}$ & 4 & 5 & 7 & 93 & 15 & 75 & 16 & 43 & 22 \\
\hline $9 \mathrm{MMCCRr}$ & 7 & 4 & 2 & 97 & 18 & 71 & 13 & 46 & 24 \\
\hline $10 \mathrm{MmCcRR}$ & 5 & 6 & 4 & 102 & 19 & 79 & 15 & 47 & 26 \\
\hline $11 \mathrm{MmCcrr}$ & - & - & - & - & $9(14)$ & 72 & 13 & 43 & 24 \\
\hline $12 \mathrm{MMCcrr}$ & - & - & - & - & $1(1)$ & 5 & 2 & 61 & 2 \\
\hline $13 \mathrm{mmCcRR}$ & 20 & 11 & 12 & 10 & 2 & 8 & 2 & 54 & 1 \\
\hline $14 \mathrm{MmCCRr}$ & 19 & 15 & 16 & 27 & 4 & 8 & 4 & 57 & 5 \\
\hline $15 \mathrm{MmccRr}$ & 22 & 13 & 14 & 26 & 4 & 7 & 6 & 55 & 3 \\
\hline $16 \mathrm{MMCcRR}$ & 0 & 0 & 0 & 16 & 2 & 0 & 3 & 0 & 2 \\
\hline $17 \mathrm{mmCcrr}$ & - & - & - & - & 1 (1) & 0 & 4 & 0 & 0 \\
\hline $18 \mathrm{mmCCrr}$ & - & - & - & - & $1 \quad(2)$ & 0 & 14 & 0 & 0 \\
\hline 19 MMccRR & 0 & 5 & 6 & 2 & $6(0)$ & 0 & 17 & 0 & 3 \\
\hline $20 \mathrm{mmccrr}$ & - & - & - & - & 0 & 7 & 0 & 2 & 1 \\
\hline 21 MMCCRR & 0 & 0 & 0 & 18 & 0 & 5 & 1 & 3 & 0 \\
\hline $22 \mathrm{mmCCRr}$ & 0 & 0 & 0 & 0 & 0 & 0 & 0 & 1 & 0 \\
\hline $23 \mathrm{MMccRr}$ & 0 & 1 & 2 & 2 & 0 & 0 & 2 & 0 & 1 \\
\hline $24 \mathrm{MmCCRR}$ & 0 & 0 & 0 & 3 & 0 & 0 & 0 & 5 & 0 \\
\hline $25 \mathrm{Mmccrr}$ & - & - & - & - & $0 \quad(0)$ & 1 & 0 & 6 & 0 \\
\hline $26 \mathrm{mmCCRR}$ & 0 & 0 & 0 & 1 & 0 & 0 & 0 & 3 & 0 \\
\hline 27 MMccrr & - & - & - & - & $0 \quad(0)$ & 0 & 0 & 2 & 0 \\
\hline
\end{tabular}


Table III

Origin of the genetypes listed in Table II. $P$ = parental non-crossover gamete; I = gamete with crossover in region I. II $=$ gamete with crossover in region II; I $\$$ II $\varnothing$ double crossover gamete. In test 1-3, region I corresponds to c-r, and region II to r-m. In tests 4-5, 7, 9 region I corresponds to c-r, and region II to c-m. In test 6, 8 region I corresponds to r-m and region II to $\mathrm{m}-\mathrm{c}$.

\begin{tabular}{|c|c|c|c|}
\hline \multicolumn{3}{|c|}{ Genotypes in tests } & \\
\hline $1,2,3$ & $4,5,6,7$ & 6,8 & \\
\hline 1 & 1 & 1 & $\mathrm{P} \times \mathrm{P}$ or $\mathrm{I} \times \mathrm{I}$ or II $\times \mathrm{II}$ or $\mathrm{I}+\mathrm{II} \times \mathrm{I}+\mathrm{II}$ \\
\hline 2 & 2 & 2 & $P \times P$ \\
\hline 3 & 3 & 3 & $\mathbf{P} \times \mathbf{P}$ \\
\hline 12 & 8 & 8 & $P \times I$ \\
\hline 13 & 9 & 9 & $P \times I$ \\
\hline 14 & 10 & 10 & $P \times I$ or I $+I I \times I I$ \\
\hline 15 & 11 & 11 & $\mathrm{P} \times \mathrm{I}$ or I $+\mathrm{II} \times \mathrm{II}$ \\
\hline 4 & 4 & 12 & $\mathrm{P} \times \mathrm{II}$ \\
\hline 5 & 5 & 13 & P $\times$ II \\
\hline 6 & 6 & 14 & $P \times I I$ or I + II $\times I$ \\
\hline 7 & 7 & 15 & $\mathrm{P} \times \mathrm{II}$ or I $+\mathrm{II} \times \mathrm{I}$ \\
\hline 8 & 12 & 4 & $\mathrm{P} \times \mathrm{I}+\mathrm{II}$ \\
\hline 9 & 13 & 5 & $P \times I+I I$ \\
\hline 10 & 14 & 6 & $\mathrm{P} \times \mathrm{I}+\mathrm{II}$ or $\mathrm{I} \times \mathrm{II}$ \\
\hline 11 & 15 & 7 & $\mathrm{P} \times \mathrm{I}+\mathrm{II}$ or $\mathrm{I} \times \mathrm{II}$ \\
\hline 22 & 16 & 24 & I $\times$ II \\
\hline 23 & 17 & 25 & I $\times$ II \\
\hline 26 & 20 & 20 & I $\times$ I \\
\hline 27 & 21 & 21 & I $\times$ I \\
\hline 18 & 18 & 26 & II $\times$ II \\
\hline 19 & 19 & 27 & II $\times$ II \\
\hline 24 & 24 & 16 & $I+I I \times I$ \\
\hline 25 & 25 & 17 & $I+I I \times I$ \\
\hline 16 & 22 & 22 & $I+I I \times I$ \\
\hline 17 & 23 & 23 & $I+I I \times I$ \\
\hline 20 & 26 & 18 & $\mathrm{I}+\mathrm{II} \times \mathbf{I}+\mathrm{II}$ \\
\hline 21 & 27 & 19 & $I+I I \times I+I I$ \\
\hline
\end{tabular}

test plants homozygous for $f c$ are sublethal as mentioned under Materials and Methods. Only 205 of the 275 chlorina plants in the $F_{2}$ reached maturity and could be tested in $F_{3}$. Assuming equal lethality in all nine $f c f c$ genotypes the distribution of the 275 chlorina plants can be calculated and is given in parenthesis.

The genotypes listed in Table II result from various combinations of non-crossover gametes, gametes carrying one crossover and gametes carrying two crossovers as tabulated in Table III. As genotypes resulting from non-crossover gametes with gametes carrying a double crossover $(\mathrm{P} \times \mathrm{I}+\mathrm{II})$ are less frequent than genotypes resulting from a fertilization between non-crossover gametes and single crossover gametes (P x I, P x II) the order of the three markers involved in each three point test can be derived from Tables II and III. The result is graphically presented in Figure 3, which also contains the recombination frequencies determined by the approximate method. Good agreement is obtained with the distances reported earlier (24). The interval between cer-f and $a c_{2}$ averages here 2,8 centimorgan versus 2,3 in (24). The distance $a c_{2}$ to ert-d with 2.8 compares to 2.5 , that of $a c_{2}$ to ert-m with 13.3 to 12.8 and the interval $a c_{2}$ to ert- $a$ with 9.4 to 8.5 centimorgan. In these three tests the frequency of observed double crossovers is consistently higher than the expectation (Table IV) leading to coefficients of 


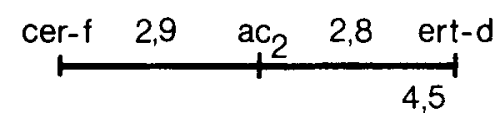

14,7
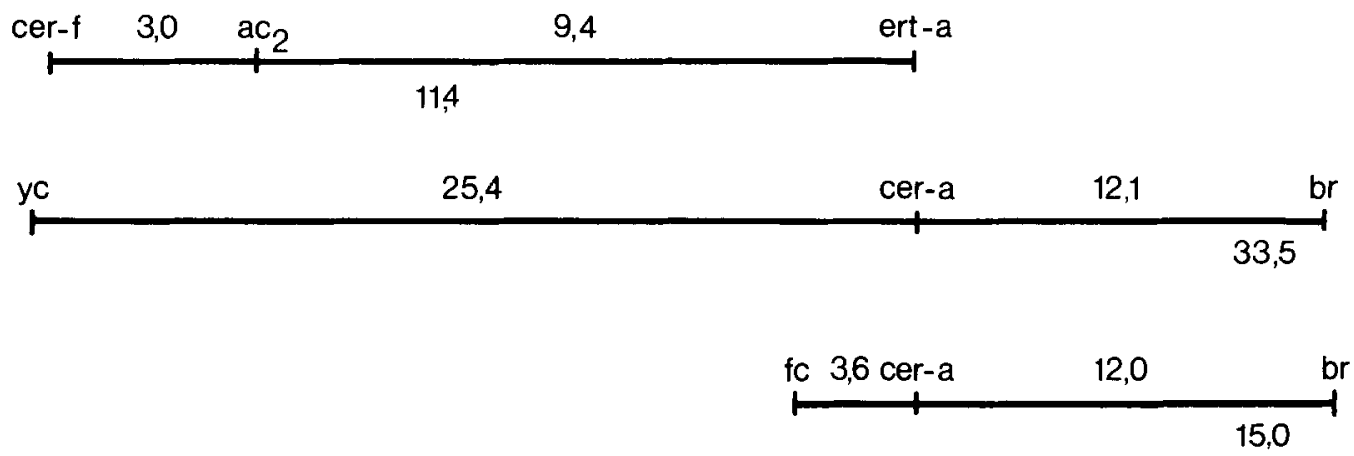

Figure 3. Distances on chromosome 1 based on the approximate method.

Table IV

Distances obtained from the estimated frequencies for the various genotypes as derived from the first principle according to the approximate method (14).

\begin{tabular}{l|r|r|r|r|r|r|r|r|r}
\hline Test number & 1 & 2 & 3 & 4 & 5 & 6 & 7 & 8 & 9 \\
\hline $\begin{array}{l}\text { Total number of gametes } \\
\text { Crossovers in region I }\end{array}$ & 2736 & 2248 & 1914 & 1932 & 2260 & 3120 & 1948 & 2436 & 2362 \\
$\begin{array}{l}\text { Crossovers in region II } \\
\begin{array}{l}\text { Crossovers in I + II } \\
\text { (double) }\end{array}\end{array}$ & 74 & 283 & 57 & 461 & 80 & 351 & 84 & 228 & 114 \\
$\begin{array}{l}\text { Crossover frequency in } \\
\text { region I in \% }\end{array}$ & 22 & 18 & 18 & 24 & 6 & 0 & 12 & 10 & 8 \\
$\begin{array}{l}\text { Crossover frequency in } \\
\text { region II in \% }\end{array}$ & 2.8 & 2.6 & 3.0 & 23.9 & 3.5 & 11.3 & 4.3 & 9.4 & 4.8 \\
$\begin{array}{l}\text { Double crossovers, } \\
\text { expected }\end{array}$ & 2.7 & 12.6 & 9.5 & 12.2 & 12.0 & 1.1 & 25.3 & 11.5 & 9.1 \\
$\begin{array}{l}\text { Double crossovers, } \\
\text { observed }\end{array}$ & 0.0008 & 0.0031 & 0.0028 & 0.0290 & 0.0042 & 0.0012 & 0.0109 & 0.0107 & 0.0044 \\
\hline
\end{tabular}

coincidence between 2.6 amd 10.5 (Table V) confirming the strong negative interference for this region.

The first case of negative interference has been reported for the centromere region of chromosome 3 in Drosophila melanogaster by
Morgan, Sturtevant \& Bridges $(2,13)$. These authors also noted that coincidence values change with the chromosomal region studied and noted that in the second and third chromosomes the coincidence values are highest near the mid-points (centromeres) and 
Table V

The coefficient of coincidence found in the nine three point tests.

\begin{tabular}{c|c|c}
\hline \multicolumn{2}{c}{ Coefficient of coincidence } \\
\hline Test number & $\begin{array}{c}\text { and standard deviation found by } \\
\text { maximum likelihood method }\end{array}$ & $\begin{array}{c}\text { found by estimation method from } \\
\text { the first principle }\end{array}$ \\
\hline 1 & $7.3 \pm 1.6$ & 10.5 \\
2 & $1.7 \pm 0.5$ & 2.6 \\
3 & $1.9 \pm 0.6$ & 3.4 \\
4 & $0.7 \pm 0.1$ & 0.4 \\
5 & $0.7 \pm 0.3$ & 0.6 \\
6 & $0.3 \pm 0.4$ & 0.0 \\
7 & $0.5 \pm 0.2$ & 0.6 \\
8 & $0.3 \pm 0.1$ & 0.4 \\
9 & $0.9 \pm 0.3$ & 0.8 \\
\hline
\end{tabular}

fall off rapidly and symmetrically on each side. In the acrocentric $X$ chromosome on the other hand the highest conincidence values were not found close to the contromere but again in the middle portion of the chromosome. M. M. GREEN (9) has reinvestigated and confirmed the occurrence of negative interference in the centromere region of chromosome 3 in Drosophila with coincidence values ranging from 1.5 to 2.8. Considerable higher negative interference (10.5) was obtained for the cer-f. $a c_{2}$, ert-d three point test in barley. As noted earlier (24) the coincidence value drops, but remains above 1 when the crossover distance in region II increases from 2.8 to 13.3 centimorgan ( $a c_{2}$ to ert- $a$ and $a c_{2}$ to ert-m).

The gene $a c_{2}$ is placed on the short arm of chromosome 1 by TsuchiYA \& Singh (28) by means of telotrisomics analyses and considered to be close to the contromere because of absent crossover with translocation break points in the short arm (5). Gene ert- $m$ has been placed by PERsson (15) to the short arm of chromosome 1 with the aid of translocations. There is thus some evidence that the region cer-f-ac $c_{2}-e r t-d$ is close to the contromere which suggest that the negative interference in this region in barley is comparable to the phenomenon in Drosophila.

The other two three point tests on chromosome 1 in barley (Fig. 3, Tables III, IV, $\mathrm{V})$ permit the ordering of the four markers $y c$, $f c$, cer-a and $b r$ in agreement with the map derived from two-point tests. Positive interference is found in this chromosome region. The maps of the two regions with distances calculated by the maximum likelihood method $(1,4)$ and weighted by the procedure of JENSEN \& HELMS JøRGENSEN (10) are presented in Figure 1. The region $y c$ to $b r$ is in the short arm of chromosome 1 . The markers $f c, c e r-a$ and $b r$ have been placed in the short arm by means of telotrisomics (27) with br most distal (7). Definitive information on the location of $y c$ relative to ert-m is not available but the distances obtained by two point tests, which are collected in Table VI all support a location of $y c$ between ert- $m$ and $f c$. The recombination frequencies of the intervals ert- $a$ to $y c$, ert-a to cer- $a$, ert- $m$ to cer- $a$, ert- $a$ to $y c$ and $a c_{1}$ to cer-a give roughly a range of 1 to 16 per cent crossover between $e r t-m$ and $y c$.

\subsection{Chromosome 3}

The results of the three point tests are presented in Figure 4 with the crossover values obtained by the approximate method. The sequence of the genes has to be as depicted in Figure 2, but the distance between cer-r and $c e r-z n$ will have to be redetermined as the distances between cer-zd and cer-zn in three point tests number 7 and 8 cannot be satisfactorily reconciled. Coincidence values are less than one indicating positive interference (Table V). Comparison of the distances determined here 
Table VI

Recombination frequencies and standard deviations (S.D.) from the present three point tests compared with earlier results from two point tests. Data in parenthesis are from materials with abnormal segregation ratios. Distances in italics were obtained by summation of distances determined with intermediate marker.

\begin{tabular}{|c|c|c|c|c|c|}
\hline & \multirow{2}{*}{$\begin{array}{c}\text { This work } \\
\begin{array}{c}\text { Recombination } \\
\text { frequency and S.D. }\end{array}\end{array}$} & \multicolumn{4}{|c|}{ Earlier work } \\
\hline & & $\begin{array}{c}\text { Recombination } \\
\text { frequency and S.D. }\end{array}$ & Generation & $\mathrm{n}$ & References \\
\hline 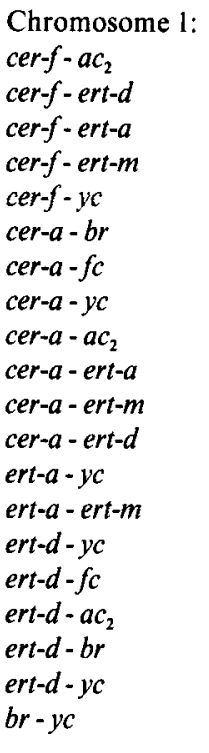 & $\begin{array}{r}2.8 \pm 0.2 \\
5.5 \pm 0.4 \\
12.5 \pm 0.8 \\
15.2 \pm 2.8 \\
12.1 \pm 0.5 \\
3.6 \pm 0.4 \\
25.4 \pm 1.4\end{array}$ & $\begin{array}{c}(4.7 \pm 1.0) \\
(2.4 \pm 0.7) \\
12 \pm 3 \\
13.3 \pm 1.8 \\
17.0 \pm 1.5 \\
12.9 \pm 2.1 \\
3.5 \pm 0.9 \\
24.4 \pm 1.6 \\
39.9 \pm 2.0 \\
36 \pm 3 \\
36.1 \pm 2.4 \\
45 \pm 3 \\
20.4 \pm 1.8 \\
17.2 \pm 4.4 \\
0 \\
\text { free } \\
1.2 \pm 0.7 \\
\text { free } \\
24.6 \pm 2.8 \\
35.5 \pm 4.2\end{array}$ & $\begin{array}{l}F_{3} \\
F_{3} \\
F_{2} \\
F_{3} \\
F_{3} \\
F_{3} \\
F_{3} \\
F_{3} \\
F_{3} \\
F_{2} \\
F_{3} \\
F_{2} \\
F_{2} \\
F_{2} \\
F_{2} \\
F_{2} \\
F_{2} \\
F_{2} \\
F_{2} \\
F_{2}\end{array}$ & $\begin{array}{l}224 \\
229 \\
793 \\
208 \\
315 \\
124 \\
187 \\
346 \\
339 \\
817 \\
201 \\
644 \\
647 \\
476 \\
438 \\
414 \\
145 \\
521 \\
302 \\
228\end{array}$ & $\begin{array}{l}(26) \\
(26) \\
(26) \\
(26) \\
(26) \\
(26) \\
(26) \\
(26) \\
(26) \\
(26) \\
(26) \\
(26) \\
(14) \\
(15) \\
(15) \\
(15) \\
(15) \\
(15) \\
(15) \\
(15)\end{array}$ \\
\hline $\begin{array}{l}\text { Chromosome 3: } \\
\text { cer-zd-ert-c } \\
\text { cer-zd-uz } \\
\text { cer-r-cer-zd } \\
\text { cer-r-ert-c } \\
\text { cer-r-uz } \\
\text { cer-zn-ert-c } \\
\text { cer-zn-uz }\end{array}$ & $\begin{array}{r}4.6 \pm 0.3 \\
10.8 \pm 0.4 \\
13.9 \pm 0.4 \\
9.0 \pm 0.4 \\
1.1 \pm 0.2 \\
19.1 \pm 0.9 \\
11.9 \pm 0.7\end{array}$ & $\begin{array}{l}(0 \quad) \\
(4.6 \pm 0.6) \\
13.5 \pm 1.7 \\
9.1 \pm 1.9 \\
0.9 \pm 0.7 \\
24 \pm 3 \\
12 \pm 3\end{array}$ & $\begin{array}{l}\mathrm{F}_{2} \\
\mathrm{~F}_{3} \\
\mathrm{~F}_{3} \\
\mathrm{~F}_{3} \\
\mathrm{~F}_{3} \\
\mathrm{~F}_{2} \\
\mathrm{~F}_{2}\end{array}$ & $\begin{array}{r}418 \\
87 \\
316 \\
126 \\
112 \\
1036 \\
914\end{array}$ & $\begin{array}{l}(25) \\
(25) \\
(25) \\
(25) \\
(25) \\
(25) \\
(25)\end{array}$ \\
\hline
\end{tabular}

$\underbrace{\text { cer-zd }}_{11,3} \quad 12,4 \quad$ uz cer-r

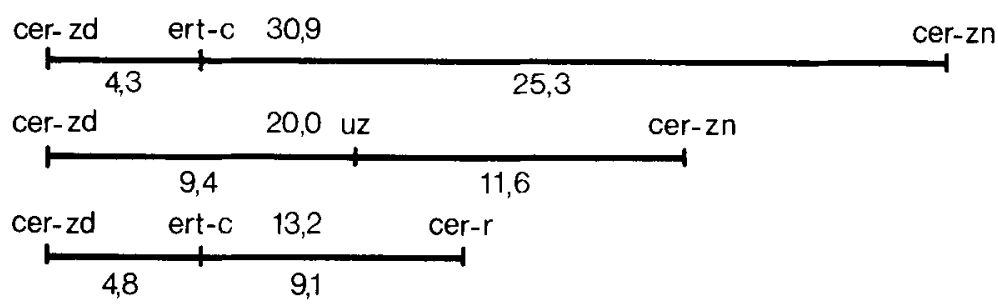

Figure 4. Distances on chromosome 3 based on the approximate method. 
with earlier results (Table VI) reveal acceptable agreement.

There has been conciderable uncertainty about the assignment of genes on chromosome 3 to its short or long arm. Thus, $u z$ has been transferred from the short arm to the long arm $(6,15)$ and back again to the short arm (20). The distance $u z$ and $e r t-c$ can roughly be calculated from the data given by EsLICK \& McPround (6) to $10 \%$ and is in agreement with the data in Figure 2. The genes $u z$ and cer-zn are considered to be located in the short arm of the chromosome with cer-zn as the most distal marker (20).

\section{ACKNOWLEDGEMENTS}

I would like to thank Professor D. von WETTSTEIN for helpful criticism during the preparation of the manuscript and the late professor O. FRYDENBERG and lic. agro. J. JENSEN for provision of the computer program to calculate the maximum likelihood estimates and for extensive discussion. I am also indebted to the personnel of the Phytotron at the Royal College of Forestry, Stockholm, for growing the plants.

\section{REFERENCES}

1. BaILeY, N. T. J.: Introduction to the mathematical theory of genetic linkage. Ciarendon Press, Oxford pp. 1-298 (1961)

2. Bridges, C. B. \& T. H. Morgan: The third-chromosome group of mutant characters of Drosophila melanogaster. Carnegie Inst. Wash., publ. 327 pp. 1-251 (1923)

3. Dormling, I., A. Gustafsson \& D. von WETTSTEIN: Phytotron cultivation of Bonus barley: The control of maturation and grain quality. Hereditas 63, 415-428 (1969)

4. Elandt-Johnson, R. C.: Probability models and statistical methods in genetics: John Wiley and Sons, New York pp. 1-592 (1971)

5. Eslick, R. F., M. M. Rahman \& C. W. CRowell: Gene ordening near the contromere of chromosome 1. Barley Genetics Newsletter 1, 20-21 (1971)

6. EsLICK, R. F. \& W. L. MCPRound: Positioning of genetic male sterile 5 (msg 5 ) on chromosome 3. Barley Genetics Newsletter 4, 16-23 (1974)

7. Fedak, G., T. Tsuchiya \& S. B. Helgason: Use of monotelotrisomics for linkage mapping in barley. Can. J. Genet. Cytol. 14, 949-957 (1972)

8. Fester, T. \& B. SøgaARd: The localization of eceriferum loci in barley. Hereditas $61,327-337$ (1969)

9. Green, M. M.: Conversion as a possible mechanism of high coincidence values in the centromere region in Drosophila. Molec. Gen. Genet. 139, 57-63(1975)

10. Jensen, J. \& J. H. JøRGENSEN: Barley chromosome 5 linkage map I. Literature survey and map estimation procedure. Hereditas 80, 5-16 (1975)

11. LUNDQvist, U. \& D. von WeTTSTEIN: Induction of eceriferum mutants in barley by ionizing radiation and chemical mutagens. Hereditas 48, 342-362 (1962)

12. LUNDQvist, U., P. von WeTtSTEIN-KNowles \& D. von WETTSTEIN: Induction of eceriferum mutants in barley by ionizing radiations and chemical mutagens. II. Hereditas 59, 473-504 (1968)

13. Morgan, T. H., A. H. Sturtevant \& C. B. BrIDGES: The genetics of Drosophila. In: Bibliographica Genetica 2, 1-262 (1925)

14. Persson, G.: An attempt to find suitable genetic markers for dense ear loci in barley. I.: Hereditas 62, 25-96 (1969)

15. Persson, G.: An attempt to find suitable genetic markers for dense ear loci in barley. II.: Hereditas 63, 1-28 (1969)

16. Persson, G. \& A. Hagberg: Induced variation in a quantitative character en barley. Morphology and cytogenetics of erectoides mutants. Hereditas 61, 115-178 (1969)

17. Persson, G. \& A. Hagberg: Building up genetic stocks of marker genes I. Transfer to Bonus genotype. Barley Genetics Newsletter 2, 115-117 (1972)

18. PowERs Le RoY: The nature of the interaction of genes affecting four quantitative characters in a cross between Hordeum deficiens and Hordeum vulgare. Genetics $21,398-420$ (1936)

19. Robertson, D. W. \& G. W. Deming: Genetic studies in barley. J. Hered. 21, 283-288 (1930)

20. SINGH, R. J. \& T. TsUChIYA: Further information on telotrisomic analysis in barley. Barley Genetics Newsletter 4, 66-69 (1974)

21. SøgaARd, B.: The location of eceriferum loci in barley. II. Cand. Scient. Thesis, Copenhagen Univ. pp. 1-28 (1970)

22. SøGaARD, B.: Linkage studies on eceriferum mutants in barley. Barley Genetics Newsletter 1 41-47 (1971)

23. SøgaArd, B.: Continued linkage studies on eceriferum mutants in barley. Barley Genetics Newsletter 3, 57-61 (1972) 
24. SøgaARd, B.: The localization of eceriferum loci in barley. III. Three-point tests of genes on chromosome 1 in barley. Hereditas 76, 41-48 (1974)

25. SøgaARd, B.: The localization of eceriferum loci in barley. IV. Three point tests of genes on chromosome 7. Carlsberg Res. Commun. 42. 6, 35-43(1977)

26. TAKAHASHI, R.: Studies on the classification and the geographical distribution of the Japanese barley varieties. I. Significance of the coleoptile length. Ber. Ohara, Inst. Landw. Forsch. 9, 71-90 (1942)

27. Tsuchiya, T.: Telotrisomic analysis of 14 marker genes on chromosome 1,2 and 4. Barley Genetics Newsletter 1, 61-62(1971)

28. Tsuchiya, T. \& R. J. Singh: Further information on the telotrisomic analysis in barley. Barley Genetics Newsletter 3, 75-78 (1973) 